\title{
Os Estados Unidos e o mundo: as Torres Gêmeas como metáfora ${ }^{*}$
}

\author{
IMMANUEL WALLERSTEIN
}

\author{
America the Beautiful: "América, a Bela" \\ O beautiful for patriot dream \\ That sees beyond the years, \\ Thine alabaster cities gleam, \\ Undimmed by human tears! \\ America! America! \\ God shed His grace on thee, \\ And crown thy good with brotherhood \\ From sea to shining sea. \\ Ó bela, pelo sonho patriótico \\ Que vê, além dos anos, \\ Tuas cidades alabastrinas reluzir, \\ Sem se toldar por lágrimas humanas! \\ América! América! \\ Deus derramou Sua graça em ti, \\ Coroa teu bem com fraternidade \\ De mar a reluzente mar.
}

America the Beautiful
"América, a Bela"

$\mathrm{E}$

M 24 DE OUTUBRO DE 1990, fui convidado para proferir a palestra inaugural da série "Palestrantes Ilustres" em comemoração ao bicentenário da Universidade de Vermont. O título da conferência era "Os Estados Unidos e o mundo: hoje, ontem e amanhã" (1), e falei sobre as bênçãos de Deus à nação norte-americana: prosperidade no presente, liberdade no passado e igualdade no futuro. Por algum motivo, porém, Deus não concedera essas bênçãos a todas as pessoas em todos os lugares. Observei o quanto os norte-americanos pareciam cientes dessa distribuição pouco eqüitativa da graça divina. Afirmei que os Estados Unidos sempre haviam se definido, sempre haviam medido suas bênçãos, tomando o mundo como parâmetro. Nossa situação foi melhor, é melhor e será melhor que a dos demais. Talvez bênçãos universais não possam ser consideradas verdadeiras bênçãos. Talvez imponhamos a Deus a exigência de que Ele salve apenas uma minoria.

Hoje vivemos sob o espectro de um acontecimento que nos abalou sobremaneira: a destruição das Torres Gêmeas, em 11 de setembro de 2001, por um grupo de indivíduos tão dedicados à sua ideologia e à sua fúria moral contra os Estados Unidos, que conspiraram durante anos até encontrarem meios de desfe-

* Palestra comemorativa feita pelo autor no Brooklyn College em 5 de dezembro de 2001. 
rir um golpe geopolítico mortal contra nós e contra aqueles que, a seu ver, nos apóiam ao redor do mundo - um golpe que exigiu o sacrifício de suas próprias vidas. A maioria dos norte-americanos reagiu a esses eventos com intensa raiva e determinação patriótica, mas, ao mesmo tempo, com profunda e persistente perplexidade. Perplexidade acerca de duas coisas: por que isso aconteceu? E como pôde ter acontecido? Nossa perplexidade foi entremeada com uma boa dose de incerteza: O que deve ser feito, o que pode ser feito para que tais eventos jamais venham a se repetir?

Revendo minhas palavras de 12 anos atrás, não desejo mudar nada. Mas sinto um certo desconforto com a postura que assumi na época. Eu preparei a palestra como se fora um etnógrafo vindo de algum outro mundo, de Marte talvez, e tentasse compreender essa espécie curiosa, o humanus americanus. Hoje não acredito que isso baste. Sou, por certo, um ser humano, e preocupado com o destino da humanidade; mas sou também um cidadão norte-americano. Nasci aqui. Vivi aqui a maior parte da minha vida. E partilho plena responsabilidade com todos os demais em minha posição, pelo que aconteceu e pelo acontecerá aqui. Tenho a obrigação moral de ver os Estados Unidos do seu íntimo.

Assim, gostaria hoje de olhar para os Estados Unidos e o mundo uma segunda vez. Mas não quero mais divisar o modo como nós, norte-americanos, vemos a nós mesmos através do prisma do mundo, e sim discernir como enxergamos o mundo no passado e como poderemos talvez querer enxergá-lo daqui para frente. Estou bem ciente de que caminho em terras controversas.

Raros foram os presidentes norte-americanos, pelo menos no século XX, que não tenham em algum momento declarado que os Estados Unidos são the greatest country in the world - o "maior e melhor" país do mundo. Não sei se nossos onipresentes órgãos de pesquisa da opinião pública já fizeram alguma vez essa pergunta diretamente, mas desconfio que a porcentagem da população norte-americana que concorda com essa afirmação seja bastante elevada. Mas peçolhes que reflitam como essa afirmação soa para os ouvidos não só de pessoas de países pobres com culturas muito diferentes, mas também de nossos amigos e aliados - os canadenses, os ingleses e, é claro, os franceses. Será que Tony Blair julga que os Estados Unidos são o maior e melhor país do mundo, maior e melhor que a Grã-Bretanha? Será que ele ousaria achar isso? Será que o papa João Paulo II acha isso? Quem, afora os norte-americanos e aqueles que desejam emigrar para os Estados Unidos, é dessa opinião?

O nacionalismo, por certo, não é um fenômeno limitado aos Estados Unidos. Os cidadãos de quase todos os países são patrióticos - e freqüentemente chauvinistas. Os norte-americanos sabem disso, com certeza. Mas tendem a ressaltar que muitas pessoas, no mundo inteiro, querem emigrar para os Estados Unidos e que nenhum outro destino imigratório parece ser tão popular - e tomam isso como uma confirmação da sua crença na virtude superior dos Estados Unidos como nação. 
A bandeira norte-americana tremula diante da silhueta da Estátua da Liberdade

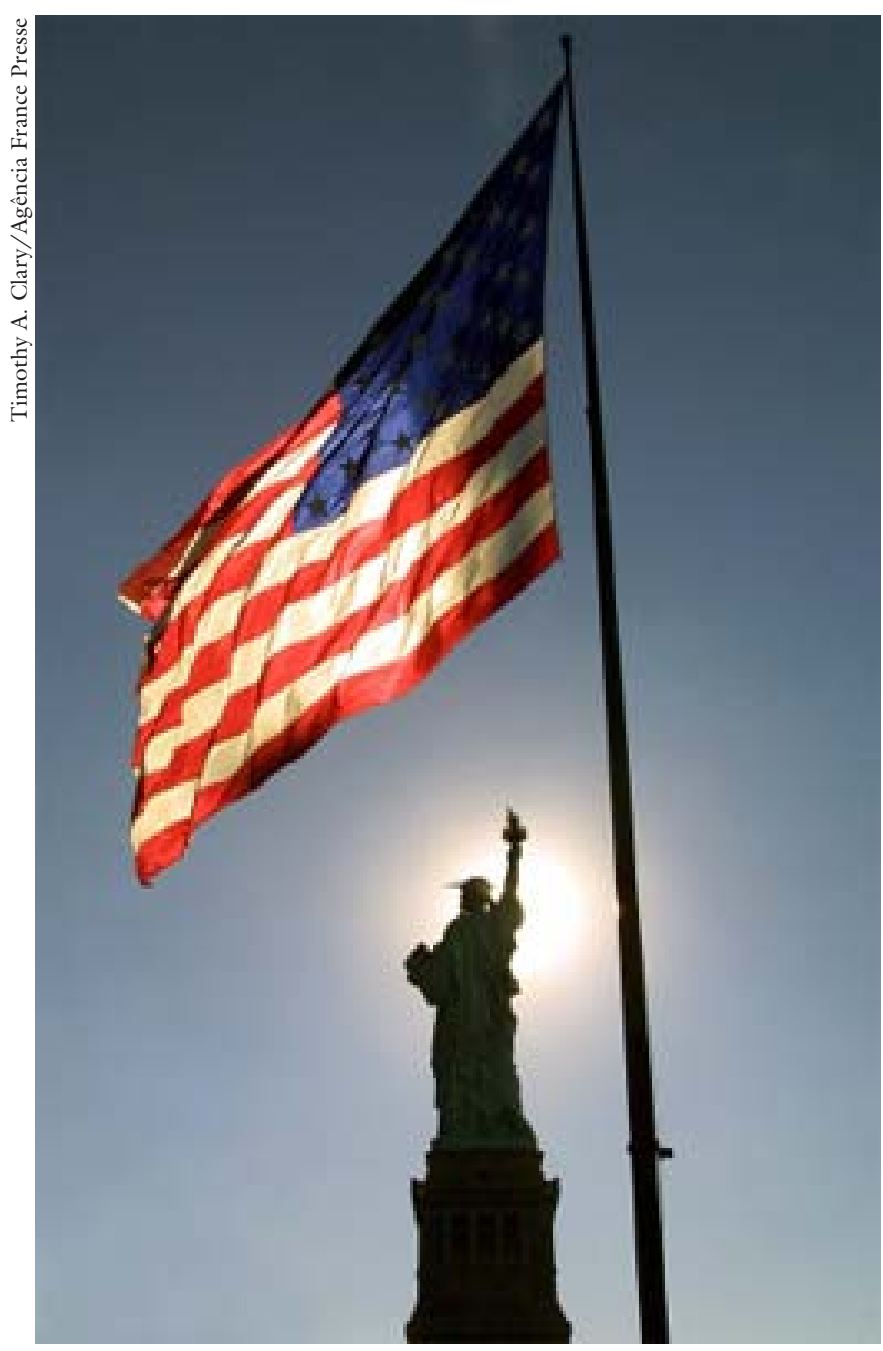

Mas, para nós, no que consiste essa virtude superior? Creio que os norteamericanos tendem a acreditar que os outros têm menos de muitas coisas que nós possuímos e que o fato de termos mais dessas coisas é um indício de graça. Tentarei, pois, esboçar vários contextos em que esse conceito de "insuficiência" (less-ness) aparece. Começarei com uma noção acerca da qual a maioria dos norte-americanos parece não nutrir dúvida alguma, a saber, que os outros países são menos modernos - modernidade significando grau de desenvolvimento tecnológico. Os Estados Unidos possuem a tecnologia mais avançada do mundo, que se encontra nos aparelhos em nossas casas por todo o país, nas redes de comunicações e transporte, na infra-estrutura nacional, nos instrumentos da exploração espacial e, é claro, no equipamento militar disponível às nossas Forças Armadas. Como resultado desse acúmulo de tecnologia, os norte-americanos consideram que a vida nos Estados Unidos é mais confortável, que a nossa produção compete com mais sucesso no mercado mundial e que, portanto, nós certamente venceremos qualquer guerra a que outros possam nos arrastar. 
Acreditamos também que a nossa sociedade é mais eficiente. As coisas aqui correm mais suavemente - no local de trabalho, no cenário público, nas relações sociais, no trato com burocracias. Por mais que possamos reclamar dessas práticas, parece-nos que as pessoas de outros lugares resolvem esse tipo de coisa ainda pior do que nós. Ninguém parece ter o mesmo grau de energia e ambição que temos: todos são menos inventivos na busca de soluções a problemas grandes ou pequenos, todos estão enredados em modos tradicionais e/ou formais de agir. Isso os emperra, enquanto os Estados Unidos não param de avançar. Conseqüentemente, estamos sempre prontos para oferecer conselhos amigos a todo mundo - aos nigerianos, aos japoneses, aos italianos - sobre como poderiam fazer melhor as coisas. A capacidade de imitar os modos norte-americanos é considerada uma grande vantagem quando avaliamos um outro país. Uma mistura de Daniel Boone + Peace Corps constitui a base para uma avaliação de economia política comparada.

Por outro lado, é claro que a maioria dos norte-americanos negará que a insuficiência alheia seja apenas material. Ela é também espiritual ou - se parecer que o termo "espiritual" exclui os humanistas seculares - ela é também cultural. Nossos presidentes proclamam e nossos hinos patrióticos confirmam que somos a terra da liberdade. Os outros são menos livres do que nós. A Estátua da Liberdade estende a sua mão para todas aquelas "massas exaustas, pobres e confusas ansiando por respirar liberdade".

A densidade da nossa liberdade é visualizada de muitas maneiras. Que outro país tem a Bill of Rights? * Onde mais as liberdades de imprensa, religião e expressão são tão respeitadas? Em que outro lugar os imigrantes são tão integrados ao sistema político? Alguém pode citar algum outro país onde alguém que lá chegou na adolescência - e que ainda hoje fala inglês com forte sotaque alemão - tornou-se secretário de Estado, o principal representante dos norte-americanos perante o resto do mundo? Existe algum outro país em que a mobilidade social, para quem tenha mérito, seja tão rápida? E qual país se compara ao nosso no tanto que somos democráticos? Democráticos não apenas na sempiterna abertura de nossas estruturas políticas e na centralidade de um sistema bipartidário, mas também em nossos costumes do dia-a-dia? Os Estados Unidos não são o país que mais se destaca em preservar o princípio de "primeiro a chegar, primeiro a ser atendido" nas ações da vida diária, em oposição a um sistema que dá preferência àqueles que têm privilégios (sendo que esses costumes democráticos, tanto no cenário público como na vida social, datam de no mínimo 200, se não quase 400 anos)?

De melting pot ** à multiculturalidade, sempre nos orgulhamos da incrível mistura étnica da verdadeira vida norte-americana - em nossos restaurantes, nos-

* Bill of Rights são as dez primeiras emendas à Constituição, promulgadas em 1791, garantindo diversos direitos aos cidadãos. (N. do T.)

** Melting point é o famoso "cadinho" onde se misturam todas as raças, credos e povos. (N. do T.) 
sas universidades, nossas lideranças políticas. Claro, temos falhas, mas nos esforçamos mais do que qualquer outro país para tentar superá-las. Ao longo das últimas décadas não estivemos sempre na vanguarda para derrubar as barreiras de sexo e raça, numa busca sempre renovada da meritocracia perfeita? Mesmo nossos movimentos de protesto são motivo de orgulho: onde mais eles são tão persistentes, tão diversos, tão legítimos?

E na única arena em que, até 1945, tendíamos a admitir que não éramos a vanguarda do mundo, a da alta cultura, também isso não mudou desde então? Nova York não é hoje o centro mundial da arte, do teatro, da música, da dança, da ópera? O cinema norte-americano é tão superior que o governo francês precisa recorrer a medidas protecionistas para impedir que as platéias francesas assistam a um número ainda maior de nossos filmes.

Podemos resumir tudo isso numa frase que os nortesamericanos não têm usado muito, pelo menos não até $11 \mathrm{de}$ setembro, mas que está sempre em nos-

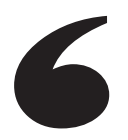

\section{... somos mais civilizados do que o resto do mundo ...}

sos corações: somos

mais civilizados do

que o resto do mundo

- do que o Velho Mundo, como costumávamos dizer com um certo ar de desdém. Nós representamos as aspirações máximas de todos os indivíduos, não apenas dos norte-americanos. Somos os líderes do mundo livre porque somos o país mais livre do mundo, e todos buscam a nossa liderança para manter altivo o estandarte da liberdade, da civilização.

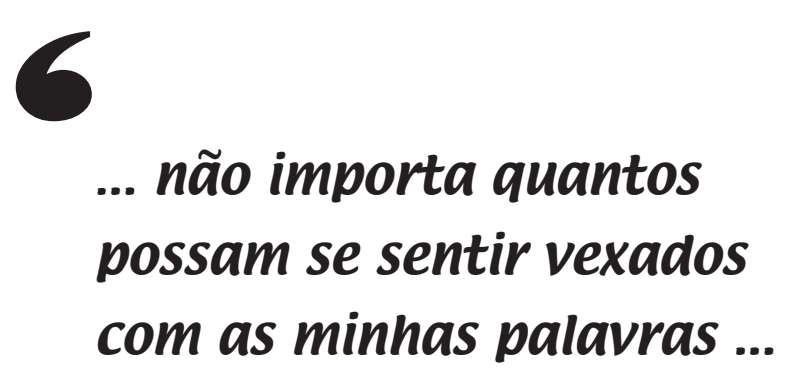

Não estou sendo irônico. Estou plenamente convicto de que essa imagem da insuficiência do resto do mundo está profundamente arraigada na psique norte-americana, não importa quantos possam se sentir vexados com as minhas palavras, insistindo que não fazem parte desse consenso e que, por assim dizer, são mais cosmopolitas em seus pontos de vista. É neste sentido, acima de tudo, que as Torres Gêmeas constituem uma metáfora perfeita. Elas apontavam para aspirações ilimitadas; anunciavam grandes feitos tecnológicos; eram um luzeiro para o mundo. 


\section{O ataque aos Estados Unidos}

O que os Estados Unidos estão provando hoje é muito pouco comparado com o que temos provado há dezenas de anos. Nossa nação vem sofrendo humilhação e desprezo há mais de 80 anos. [...] Agora que, após 80 anos, a espada caiu sobre os Estados Unidos, a hipocrisia vai erguendo sua horrenda cabeça para lamentar a morte desses assassinos que perverteram o sangue, a honra e os lugares sagrados dos muçulmanos. O mínimo que se pode falar desse povo é que é moralmente depravado.

Osama bin Laden, 7 de outubro de 2001

Osama bin Laden não concorda com a idéia de America the Beautiful. Ele pensa que os norte-americanos são moralmente depravados. É verdade que hoje existem alguns norte-americanos que também pensam que a maioria de nós é moralmente depravada. É o que poderíamos chamar a "direita cultural" dos Estados Unidos. Entretanto, embora as críticas da direita cultural norte-americana e as de Osama bin Laden possam coincidir em parte, na medida em que se referem aos costumes do cotidiano, a denúncia fundamental de Bin Laden diz respeito ao que chama de "hipocrisia dos Estados Unidos" no cenário mundial. A esse respeito, há pouquíssimos norte-americanos que concordariam com tal caracterização - e mesmo aqueles que talvez dissessem algo semelhante matizariam seu ponto de vista de maneiras que Bin Laden consideraria irrelevantes e inaceitáveis.

Este foi um dos dois grandes choques dos norte-americanos em 11 de setembro. Havia no mundo pessoas que negavam qualquer indício de boa-fé nas ações e motivações dos Estados Unidos no cenário mundial. Como era possível que indivíduos que tinham menos de tudo aquilo que vale a pena ter duvidassem que aqueles que tinham mais de tudo haviam obtido isso por seu próprio mérito? A presunção moral de Bin Laden deixou pasmos os norte-americanos e os exasperou.

Evidentemente, Bin Laden não foi, nem de longe, a primeira pessoa a fazer esse tipo de ataque verbal. Mas ele foi o primeiro que conseguiu traduzir o ataque verbal num ataque físico ao solo norte-americano, que pegou o país de surpresa e, ao menos momentaneamente, deixou-o impotente. Até então, os norte-americanos sempre puderam se dar ao luxo de ignorar os ataques verbais, tão em voga no mundo quanto a tagarelice dos tolos. Só que agora os tolos haviam se tornado vilões - e vilões bem-sucedidos, ao menos de início. Este foi o segundo grande choque. Nós pensávamos estar numa posição que nos permitia ignorar tais críticas, porque éramos, em essência, invulneráveis. E subitamente descobrimos que não éramos.

Afirmou-se muitas vezes que o mundo nunca mais será o mesmo depois de 11 de setembro. Acho essa uma hipérbole meio tola. Mas é verdade que a psique norte-americana talvez nunca mais seja a mesma. Pois depois que acontece, o impensável se torna pensável. E um ataque direto ao território dos Estados Uni- 
dos por um bando disperso de indivíduos sempre fora algo impensável. Eis que tivemos de criar um gabinete de segurança interna, o Office of Homeland Security. E o Pentágono precisou decidir se estabeleceria o que chamam de "comando regional" - uma estrutura militar até então restrita a áreas fora dos Estados Unidos - para cobrir o próprio território norte-americano.

Acima de tudo, agora incluímos o termo "terrorista" em nosso vocabulário. Na década de 1950, o termo "comunista" foi largamente empregado. Abrangia não apenas pessoas que pertenciam a partidos comunistas, ou aqueles que se viam ou eram vistos por outros como "co-partidários", mas até mesmo quem não demonstrasse "entusiasmo" suficiente pela construção de uma bomba de hidrogênio. Afinal, esta foi a acusação explícita que levou a Atomic Energy Commission a cancelar a permissão de acesso de J. Robert Oppenheimer a zonas de segurança - o mesmo Oppenheimer que era conhecido e vem sendo celebrado desde então como o "pai da bomba atômica".

O termo "terrorismo" agora adquiriu o mesmo significado abrangente. Em novembro de 2001, eu assisti a um programa de televisão da série Lei e Ordem. A trama desse episódio em particular girava em torno do incêndio de um prédio em construção. Por trás, havia um empreiteiro que recebera um terreno do município que antes fora um jardim comunitário, cuidado pela vizinhança. A comunidade se opunha à nova construção. Um grupo de jovens identificados como "ativistas ambientais" decidiu atear fogo ao edifício como protesto. $\mathrm{O}$ fator complicador era que, sem que eles soubessem, havia por acidente alguém no prédio que morreu no fogo. No final, os incendiários são pegos e condenados. O interessante dessa história banal é que, durante todo o programa, os incendiários eram referidos repetidamente como "terroristas". Ora, qualquer que seja a definição de terrorista, nem mesmo por um grande esforço da imaginação o termo se aplicaria ao caso. Mas não importa! Assim foi usado e assim continuará a ser usado.

Somos a terra da liberdade. Hoje, porém, existem vozes - no governo, na imprensa, na população em geral - afirmando que concedemos liberdade demais, especialmente a não-cidadãos, e que os "terroristas" tiraram proveito da nossa liberdade. Portanto, dizem, os privilégios da liberdade precisam ceder lugar a procedimentos que atendam às nossas necessidades de segurança. Por exemplo, estamos aparentemente temerosos de que, se capturarmos "terroristas" e os levarmos a julgamento, eles poderão obter assim um foro público, escapar da condenação ou, se condenados, não receber a pena de morte. Portanto, para assegurar que nada disso aconteça, estamos criando tribunais militares a serem convocados pelo presidente, com regras estabelecidas apenas por ele, nos quais ninguém tem direito de recurso. Essas cortes funcionarão em absoluto segredo e devem ser capazes de chegar rapidamente a um veredicto - presumivelmente, pena de morte, talvez executada também em segredo. Após o julgamento, tudo 
o que nos permitirão saber é o nome da pessoa condenada. Ou talvez nem isso. E em nossa terra de liberdade isso vem sendo amplamente aplaudido, havendo, no máximo, uma oposição tépida de uma corajosa minoria.

Acreditamos, e temos afirmado publicamente, que o ataque aos Estados Unidos foi direcionado aos nossos valores e à própria civilização - um ataque totalmente sem escrúpulo. Estamos determinados a vencer a guerra mundial contra o terrorismo - contra os terroristas e todos aqueles que os abrigam e os apóiam. Estamos determinados a mostrar que, a despeito desse ataque, somos e continua- mos sendo o maior e melhor país do mundo. Para provar isso, não estamos sendo adjurados pelo presidente a fazer sacrifícios individuais - nem mesmo o pequeno sacrifício de pagar mais impostos -, mas apenas continuar levando nossas vidas como sempre. Por outro lado, espera-se que aplaudamos sem reservas tudo que o nosso governo e as nossas Forças Armadas fizerem, mesmo que não seja normal.

O grau dessa inadmissão de qualquer exceção ou reserva pode ser vista na denúncia generalizada de todos aqueles que tentam "explicar" por que os eventos de 11 de setembro aconteceram. Toda explicação é considerada uma justificação e praticamente um endosso ao terror. Em novembro de 2001, o Acta (American Council of Trustees and Alumni-Conselho Americano de Curadores e Ex-Alunos), uma organização fundada por Lynne Cheney * e pelo senador Joseph Lieberman, publicou um folheto intitulado "Defendendo a civilização: como nossas universidades estão debilitando os Estados Unidos e o que pode ser feito a respeito" ** (2). É um impresso curto, que expõe as idéias com notável vigor e concisão. Afirma-se que "os professores universitários são o elo frágil na reação dos Estados Unidos ao ataque”. E prossegue com a seguinte análise:

Raras vezes os professores se referiram publicamente ao heroísmo, raras vezes eles discutiram as diferenças entre bem e mal, a natureza da ordem política ocidental ou as virtudes de uma sociedade livre. Seus comentários públicos foram escassos em patriotismo e fartos em autoflagelação. Na verdade, a mensagem de grande parte da academia foi: Culpem primeiro os Estados Unidos!

A maior parte do folheto é dedicada a um apêndice com 117 citações que, segundo os autores, ilustram a sua tese. As citações incluem declarações não apenas de pessoas como Noam Chomsky e Jesse Jackson, mas também de alvos pouco usuais desse tipo de acusação: o diretor da Woodrow Wilson School da Universidade de Princeton, ex-vice-ministro dos Assuntos Exteriores. Em suma, os autores do folheto estavam mirando alto.

Fica claro a essa altura que, mesmo que os eventos de 11 de setembro não alterem as realidades geopolíticas básicas do mundo contemporâneo, eles poderão ter um efeito duradouro sobre as estruturas políticas norte-americanas. A

\footnotetext{
${ }^{*}$ Esposa do atual vice-presidente, Dick Cheney. (N. do T.)

${ }^{* *}$ Defending civilization: how our universities are failing America and what can be done about it. (N. do T.)
} 
intensidade desse impacto ainda permanece em aberto. Porém, ao menos por enquanto, aparentemente não há nenhum incentivo para que se tente resolver a perplexidade dos norte-americanos a que me referi antes: por que isso aconteceu? Como pôde acontecer?

As Torres Gêmeas são também uma metáfora do ataque aos Estados Unidos. Foram construídas com notável perícia de engenharia. Eram supostamente imunes a todo tipo concebível de destruição acidental ou deliberada. No entanto, parece que ninguém jamais cogitou que dois aviões repletos de querosene de aviação pudessem ser deliberadamente lançados contra elas, atingindo os prédios precisamente no ponto $-20 \%$ da altura de cima para baixo - que maximizaria a destruição. Como também ninguém antecipou que os edifícios ruiriam lentamente, espetacularmente, à vista de todos, trazendo abaixo outras construções adjacentes. Ninguém jamais previu que o incêndio provocado pelo colapso dos prédios continuaria a arder por meses a fio. Os Estados Unidos podem até se vingar do ataque, mas não podem desfazê-lo. A tecnologia revelou-se um escudo protetor bastante imperfeito.

\section{Os Estados Unidos e o poder mundial}

O anticatolicismo, conforme se desenvolveu (na Grã-Bretanha do séc. XVIII), prestava-se geralmente a uma função dialética, chamando atenção para o suposto despotismo, superstição, opressão militar e pobreza material dos regimes católicos, a fim de dar maior destaque às supostas liberdades, supremacia naval e prosperidade agrícola e comercial anglo-britânicas e, conseqüentemente, à superioridade do império.

Linda Colley (3)

Começo com esta citação de Linda Colley para lembrar que os Estados Unidos não são a primeira potência hegemônica na história do sistema mundial moderno, mas a terceira, e que a hegemonia tem suas regras culturais e também suas vulnerabilidades. Uma das regras culturais é que denegrir os outros é indispensável para manter a autoconfiança interna que torna possível o exercício eficaz do poder em escala mundial.

Nada ofusca a percepção mais do que o sucesso. E os Estados Unidos tiveram uma farta dose de sucessos nos últimos 200 anos. O sucesso tem uma conseqüência nefasta: é quase inevitável que gere a convicção de que irá necessariamente se perpetuar. O sucesso é um péssimo norteador para diretrizes prudentes. O fracasso costuma pelo menos levar à reflexão; com o sucesso, isso raramente acontece.

Há 50 anos, a hegemonia norte-americana no sistema mundial baseava-se numa combinação de eficiência produtiva (superando, em muito, a de qualquer rival), um programa político enfaticamente endossado pelos aliados na Europa e na Ásia, e superioridade militar. Hoje, a eficiência produtiva das empresas norte- 
americanas enfrenta vigorosa concorrência das empresas de nossos aliados mais próximos. Como resultado, o programa político mundial dos Estados Unidos já não conta com o mesmo apoio enfático; pelo contrário, costuma ser contestado até por nossos aliados, ainda mais depois do desaparecimento da União Soviética. O que ainda nos resta, por ora, é a superioridade militar.

Vale a pena refletirmos sobre os objetivos da política externa norte-americana, conforme aplicada nos últimos 50 anos por sucessivos governos. Obviamente, os Estados Unidos sempre mostraram preocupação com a ameaça representada por governos que consideramos hostis ou, no mínimo, antagônicos aos nossos interesses. Não há nada de errado ou excepcional nisso, pois o mesmo acontece na política externa de qualquer Estado do sistema mundial moderno - e certamente na de qualquer Estado poderoso. A questão é como os Estados Unidos pensavam que poderiam lidar com tais ameaças.

Nas décadas de 1950 e 1960, os Estados Unidos pareciam tão fortes que, sem grandes dificuldades e com um uso mínimo de força, éramos capazes de neutralizar governos de que não gostássemos (chamávamos isso de contenção), ou derrubar governos mais fracos apoiando dissimuladamente forças internas de oposição - com a ajuda ocasional de um pouco da boa e velha gunship diplomacy, a diplomacia com canhoneiras.

Neutralização era a tática empregada em relação ao mundo comunista. Os Estados Unidos nunca pretenderam derrubar a União Soviética ou qualquer de seus regimes-satélite na Europa Oriental e Central. Basicamente, não pretenderam isso porque não tinham condições militares de confrontar a resistência esperada do governo soviético. Ao invés, o governo norte-americano firmou um acordo tácito com a União Soviética de que sequer tentaria derrocá-la em troca da promessa de que os soviéticos não tentariam ampliar a sua zona de influência. Referimo-nos a isso em código como o Acordo de Yalta. Se alguém duvida da realidade desse acordo, basta estudar a política externa dos Estados Unidos em relação à República Democrática Alemã em 1953, à Hungria em 1956, à Checoslováquia em 1968 e à Polônia em 1981.

Entretanto, o acordo não abrangia o Leste da Ásia, onde não havia tropas soviéticas, graças primordialmente à insistência dos regimes comunistas da China e Coréia do Norte. Os Estados Unidos tentaram, de fato, derrubar esses regimes e também o do Vietnã. Não fomos bem-sucedidos, no entanto. E essas tentativas malogradas deixaram uma feia cicatriz na opinião pública norte-americana.

Mas os Estados Unidos foram capazes de impor sua vontade ao resto do mundo, e o fizeram sem qualquer compunção. Basta pensar no Irã em 1953, Guatemala em 1954, Líbano em 1956, República Dominicana em 1965 e Chile em 1973. O golpe no Chile, perpetrado com o apoio ativo do governo norteamericano pelo general Pinochet contra o governo livremente eleito de Salvador Allende, ocorreu em 11 de setembro. Não sei se Osama bin Laden ou seus segui- 
dores estavam cientes desta aposição de datas, mas não deixa de ser uma coincidência simbólica que muitas pessoas, especialmente na América Latina, não deixarão de reparar. Isso também aponta para outra metáfora das Torres Gêmeas: elas foram um extraordinário feito tecnológico. Mas feitos tecnológicos podem e serão copiados. A Malásia já as copiou arquitetonicamente e um arranha-céu ainda mais alto está sendo construído atualmente em Xangai. Símbolos também podem ser copiados. Agora temos duas comemorações com vítimas em 11 de setembro.

Na década de 1970, os métodos da política externa dos Estados Unidos mudaram - tiveram que mudar. O Chile foi a última grande ocasião em que os Estados Unidos conseguiram organizar com tamanha insolência um outro governo em conformidade com suas preferências. (Não incluo os casos de Granada e Panamá, países minúsculos sem qualquer possibilidade séria de defesa militar.) O que provocou essa mudança foi o fim do domínio econômico norte-americano na economiamundo, combinado com a derrota militar dos Estados Unidos no Vietnã. A realidade geopolítica mudou. $\mathrm{O}$ governo norte-americano não pôde mais se dedicar a manter, e muito menos a expandir, o seu poderio. Ao contrário, seu objetivo primordial tornou-se impedir uma erosão acelerada demais do seu poder - tanto na economia-mundo como no contexto militar.

$\mathrm{Na}$ economia-mundo, os Estados Unidos começaram a enfrentar não só o avanço ávido de seus concorrentes na Europa Ocidental e no Japão, mas também o aparente sucesso de políticas "desenvolvimentistas" de grande parte do resto do mundo, concebidas expressamente para restringir a capacidade percebida de os países centrais acumularem capital à custa dos países periféricos. Devemos nos lembrar de que as Nações Unidas elegeram a década de 1970 como a "década do desenvolvimento". Nesses anos falou-se muito sobre a criação de uma "nova ordem econômica internacional" e, na Unesco, da criação de uma "nova ordem internacional de informação". Na década de 1970, houve as duas célebres altas no preço do petróleo pela Opep, que lançaram ondas de pânico na população norte-americana.

A posição dos Estados Unidos em todos esses ímpetos foi ou de desconforto ambíguo ou de oposição ostensiva. Lançamos uma contra-ofensiva em escala global, com uma asserção agressiva do neoliberalismo e do chamado Consenso de Washington, a transformação do Gatt (Acordo Geral sobre Tarifas e Comércio) na Organização Mundial do Comércio, os encontros de Davos e a disseminação do conceito de globalização e de seu corolário: NHA (Não Há Alternativa). Esses esforços combinados representaram, em essência, um verdadeiro desmantelamento das políticas "desenvolvimentistas" em todo o mundo - e, é claro, particularmente nas zonas periféricas da economia-mundo. No curto prazo, ou seja, nas décadas de 1980 e 1990, essa contra-ofensiva liderada pelo governo norte-americana pareceu vitoriosa.

Essas políticas no fronte da economia-mundo tiveram como contrapartida 
uma política militar mundial persistente, que poderia ser definida como uma diretriz de "antiproliferação". Quando os Estados Unidos detonaram com êxito as primeiras bombas atômicas, em 1945, estavam determinados a manter o monopólio dessas armas poderosíssimas e dispostos a compartilhá-lo com seu fiel parceiro menor, a Grã-Bretanha, e com mais ninguém. Entretanto, como todos nós sabemos, as outras "grandes potências" simplesmente ignoraram tal pretensão. Primeiro a União Soviética, depois a França e, em seguida, a China adquiriram capacitação nuclear. O mesmo aconteceu com a Índia e, mais tarde, com o Paquistão. E também a África do Sul, embora o governo do apartheid só fosse admitir isso quando estava deixando o poder (tomando a precaução de desmantelar o arsenal nuclear antes de passar o cetro ao seu sucessor mais democrático, o governo da maioria africana negra). Para não falar em Israel, que sempre negou isso publicamente.

Temos ainda as quase potências nucleares, se é que ainda se enquadram nessa categoria: Coréia do Norte, Irã, Iraque (cujas instalações Israel bombardeou na década de 1980 para manter o país na categoria do "quase"), Líbia e, talvez, Argentina. E há também os antigos países soviéticos que herdaram sua capacidade nuclear: Ucrânia, Bielo-Rússia e Casaquistão. A tudo isso devemos acrescentar outras tecnologias letais, a das armas biológicas e químicas, que são muito mais fáceis de criar, armazenar e aplicar, embora não saibamos quantos países tenham alguma capacitação nessa área.

Os Estados Unidos têm uma política bastante simples e clara: por bem ou por mal, por força ou por suborno, queremos negar a todos o acesso a essas armas. Obviamente, não temos tido sucesso, mas nossos esforços nos últimos anos pelo menos retardaram o processo de proliferação. Há ainda um detalhe adicional na política norte-americana: ao mesmo tempo em que tentamos fazer valer os acordos internacionais que limitam a proliferação, não nos julgamos sujeitos a tais acordos, ou nos consideramos apenas minimamente sujeitos a eles. O governo norte-americano deixou bem claro que abandonará qualquer tipo de restrição nesse sentido sempre que julgar necessário, embora condene em alto e bom tom qualquer outro governo que tente fazer o mesmo.

Como política, a não-proliferação parece fadada ao fracasso, não apenas no longo prazo, mas até no médio prazo. O máximo que os Estados Unidos conseguirão fazer nos próximos 25 anos é retardar ligeiramente o processo. Mas também aqui há uma questão moral e política. Os Estados Unidos confiam em si mesmos e em mais ninguém. O governo norte-americano quer inspecionar instalações da Coréia do Norte para verificar se estão violando as normas. Mas não concedeu às Nações Unidas ou a quem quer que seja o direito de inspecionar as suas instalações. Eles acreditam que saberão usar essas armas com sabedoria e em defesa da liberdade (um conceito aparentemente congruente com os interesses nacionais norte-americanos), mas pressupõem que todos os outros países poderiam usá-las contra a liberdade (um conceito aparentemente con-gruente, também aqui, 
com os interesses nacionais norte-americanos). Pessoalmente, não julgo que governo algum possa usar tais armas com sabedoria. Ficaria feliz em ver todas elas banidas, mas não creio que isso seja exeqüível no sistema interestatal contemporâneo. Por isso, devo me abster de emitir juízos morais sobre o assunto. Aliás, emitir juízos morais é algo que só nos deixa sujeitos à acusação de hipocrisia, e embora um neorealista cínico (uma categoria em que eu possivelmente me incluo) possa dizer que todos os governos são hipócritas, essa atitude é nociva se desejarmos obter o apoio de outros países com base em nossa virtude relativa.

\section{Estados Unidos: ideais versus privilégios}

Sugerir que a civilização universal já está instituída é mostrar-se intencionalmente cego à realidade atual e, o que é pior, banaliza a meta e prejudica a materialização de uma verdadeira universalidade no futuro.

Chinua Achebe (4)

A oposição entre a globalização e as tradições locais é falsa: a globalização ressucita diretamente as tradições locais, literalmente depende delas, e é por isso que o oposto de globalização não são as tradições locais mas a universalidade.

Slavoj Zizek (5)

A história dos Estados Unidos e do poder no mundo pode ser resumida. Não acredito que esta nação e os norte-americanos sejam a causa de toda a miséria e a injustiça que há atualmente, mas que são os principais beneficiários do mundo. E este é o problema fundamental dos Estados Unidos, como nação posicionada entre outras.

Os norte-americanos, principalmente os políticos e comunicadores, gostam de falar sobre os nosso ideais. Por exemplo, um anúncio do bestseller de Chris Matthews, Now, let me tell you what I really think, * diz o seguinte: "Quando paramos para refletir a respeito, vemos que nós, norte-americanos, somos diferentes. Essa palavra, 'liberdade', está não apenas em nossos documentos, mas também em nossas almas de caubói" (6). "Almas de caubói" - não poderia ter me expressado melhor. Nossos ideais talvez sejam especiais. Mas as mesmas pessoas que costumam enfatizar isso preferem não falar sobre nossos privilégios, que talvez também sejam especiais. Na verdade, essas pessoas censuram quem ousar falar sobre isso. Ora, ideais e privilégios caminham juntos; podem parecer estar em conflito, mas uns pressupõem os outros.

Não sou alguém que denigra os ideais dos Estados Unidos. Acho-os magníficos, revigorantes. São ideais que eu estimo, invoco e promovo. Tomemos a primeira emenda da Constituição. Acertadamente, ela é sempre lembrada em todo o tipo de cerimônia como a encarnação dos ideais norte-americanos. Porém, lembremo-nos de duas coisas a respeito dela. Primeiro, ela não fazia parte da

*Deixe-me lhe dizer o que eu realmente penso. (N. do T.) 
Constituição original, o que vale dizer que não era considerada um princípio fundador. E, segundo, as pesquisas de opinião têm mostrado que a maioria do povo norteamericano modificaria, restringiria ou até eliminaria as garantias nela contidas, na totalidade ou em parte, mesmo em "épocas de paz". Agora que estamos em "guerra ao terrorismo", não é certo que nem o governo nem o povo norte-americano defenderá esses ideais. Não é sequer certo que a Suprema Corte se aterá rigorosamente a eles numa "emergência". A defesa da primeira emenda e dos ideais nela contidos acabará ficando para uma organização normalmente acanhada que, na melhor das hipóteses, tem apoio minoritário da opinião pública - a American Civil Liberties Union -, pois o simples fato de lhe pertencer costuma ser motivo para não se votar nessa pessoa numa eleição. Em suma, sou a favor da liberdade de expressão e da liberdade religiosa e de todas as demais liberdades, mas às vezes me pergunto se os Estados Unidos também o são.

O motivo, é claro, não é a ausência de um traço voltaireano no caráter do povo americano, mas o fato de às vezes temermos que nossos privilégios corram o risco de erosão ou desaparecimento. Nesses casos, a maioria das pessoas coloca os privilégios à frente dos ideais. Também aqui não há nada de incomum nos norte-americanos: nós apenas somos mais poderosos e temos mais privilégios. Os norte-americanos são mais livres para ter ideais porque são mais livres para ignorá-los. Temos o poder de sobrepujar nossas almas de caubói.

$\mathrm{Na}$ realidade, a questão com que os norte-americanos se deparam é a seguinte: se a hegemonia dos Estados Unidos está em lento declínio - como eu acredito que esteja, inquestionavelmente -, será que perderemos nossos ideais porque teremos menos poder para sobrepujá-los? Será que nossas almas de caubói vão erguer cercas de arame farpado em torno do roçado nacional para preservar os privilégios que correm o risco de diminuir (como se eles não pudessem escapar do arame farpado)? Quero sugerir mais uma metáfora que advém das Torres Gêmeas. Torres destruídas podem ser reconstruídas. Mas será que iremos reconstruí-las do mesmo modo, no mesmo espírito - com a mesma certeza de estarmos alcançando as estrelas, de estarmos fazendo a coisa certa, com a mesma certeza de que elas serão como um luzeiro para o mundo? Ou iremos reconstruílas de outra maneira, após profunda reflexão sobre o que realmente precisamos e o que é possível, realmente desejável para nós?

E quem somos "nós"? Se aceitarmos as declarações do John Ashcroft, o ministro da Justiça norte-americano, secundadas por muitos outros no governo norte-americano, na mídia e no povo em geral, esse “nós” já não inclui todos os que moram nos Estados Unidos, nem mesmo todos os residentes legais, mas apenas os cidadãos norte-americanos. E devemos nos perguntar se esse "nós" não poderá vir a ser ainda mais restrito num futuro próximo. Como ressalta Zizek, globalização não é o oposto de localismo; mas depende do localismo, especialmente do localismo dos poderosos. O "nós" não é, nem de longe, o homo sapiens sapiens. 
Será então que o homo é assim tão sapiens?

\section{Estados Unidos: da certeza à incerteza}

A revolução da Darwin deve ser caracterizada como a substituição de essência por variação como a categoria central da realidade natural. (...) O que pode ser mais entontecedor do que uma inversão cabal, ou "grande reviravolta", da nossa concepção de realidade: no mundo de Platão, a variação é um acidente, ao passo que as essências são o registro de uma realidade superior; na inversão de Darwin, passamos a valorizar a variação como uma realidade definidora (e concretamente terrena), enquanto as médias (nosso recurso operacional mais próximo das "essências") se tornaram abstrações mentais.

Stephen J. Gould (7)

A natureza está, de fato, relacionada à criação de novidades imprevisíveis, nas quais o possível é mais fértil que o real.

Ilya Prigogine (8)

O presidente Bush tem oferecido ao povo norte-americano certezas acerca do nosso futuro. Ora, isso é algo que está totalmente fora do seu alcance oferecer. O futuro dos Estados Unidos, o futuro do mundo, no curto prazo, e ainda mais no médio prazo, é absolutamente incerto. A certeza pode parecer desejável quando pensamos em nossos privilégios. Mas parecerá menos desejável se considerarmos que os privilégios estão fadados a diminuir, ou mesmo desaparecer. E se fosse certo que os Osama bin Ladens do mundo prevaleceriam em todas as áreas: quem acalentaria essa certeza?

Retomo agora a questão que levantei antes acerca da perplexidade que os norte-americanos estão sentindo hoje: o que deve ser feito, o que pode ser feito, para que algo como 11 de setembro não aconteça nem possa jamais acontecer outra vez? Pela solução que estão nos propondo, um exercício esmagador de força pelo governo, e pelas forças militares principalmente, garantirá isso. Nossos líderes são suficientemente prudentes para avisar que pode demorar um certo tempo, embora não hesitem em dar garantias de médio prazo. Por ora, parece que o povo norte-americano está disposto a testar essa hipótese. Se o governo dos Estados Unidos está recebendo críticas neste momento, elas vêem principalmente daqueles que acreditam que a nossa expressão de poderio militar é tímida demais. Há grupos importantes pressionando o governo a ir muito além: a atuar militarmente contra o Iraque e, alguns acrescentariam, Irã, Síria, Sudão, Palestina, Coréia do Norte. Por que não Cuba em seguida? Há até alguns afirmando que generais relutantes deveriam ser afastados para abrir espaço a guerreiros mais jovens e mais vigorosos. E, por fim, há aqueles que acreditam que sua função seja precipitar o Armagedom.

Podemos seguir duas linhas de contra-argumentação. A primeira é que os Estados Unidos não conseguiriam vencer uma conflagração militar tão universal. A segunda é que os Estados Unidos não haveriam de querer suportar as conseqüências 
morais, acima de tudo para si mesmos, de tentar vencê-la. Felizmente, não temos de escolher entre realismo e idealismo. Em nada denigre nossos valores morais o fato de serem confirmados pelo mais elementar bom senso.

Depois da Guerra Civil, os Estados Unidos passaram cerca de 80 anos buscando o seu destino manifesto. O país não tinha certeza, durante todo esse tempo, se queria ser uma potência isolacionista ou imperialista. E, em 1945, quando finalmente alcançou hegemonia no sistema mundial, quando (segundo a escolha de Shakespeare) não só alcançou a grandeza mas teve a grandeza lançada sobre si, o povo norte-americano não estava plenamente preparado para o papel que precisava agora representar. Passamos 30 anos aprendendo como "assumir nossas responsabilidades" no mundo. E justamente quando havíamos aprendido isso razoavelmente bem, nossa hegemonia já não estava mais no apogeu.

Passamos os últimos 30 anos insistindo em alto e bom tom que ainda somos hegemônicos e que todos precisam continuar reconhecendo isso. Mas quando se é verdadeiramente hegemônico, não é preciso fazer esse tipo de instância. Nós desperdiçamos os últimos 30 anos. O que os Estados Unidos precisam fazer agora é aprender a conviver com a nova realidade, da qual não temos mais o poder de decidir unilateralmente o que é bom para todos. Talvez não estejamos sequer nessa posição. Precisamos entrar em acordo com o resto do mundo. Mas não é com Osama bin Laden que vamos estabelecer um diálogo. Precisamos começar com nossos amigos e aliados mais próximos - com o Canadá e o México, com a Europa, com o Japão. Somente depois de havermos aprendido a ouvir o que têm a dizer e a perceber que também eles têm ideais e interesses, que eles também têm idéias e esperanças e aspirações, é que talvez estaremos prontos para dialogar com as demais nações, ou seja, com a maior parte do mundo.

Esse diálogo, uma vez iniciado, não será fácil e talvez não seja sequer agradável, pois irão nos pedir que renunciemos a alguns de nossos privilégios. Pedirão que cumpramos nossos ideais. Pedirão que aprendamos. Há 50 anos, o grande poeta e político africano, Léopold Sédar Senghor, conclamou o mundo a rendezvous du donner et du recevoir. Os norte-americanos sabem o que têm de dar em tal rendez-vous. Mas será que estamos cientes de algo que desejamos receber?

Estamos hoje sendo convocados a retornar para valores espirituais, como se já os houvéssemos observado antes. Mas quais seriam esses valores? Permitamme lhes relembrar. Na tradição cristã (Mateus 19:24), está escrito: “É mais fácil um camelo entrar pelo olho de uma agulha do que um rico entrar no reino de Deus". Na tradição judaica, Hillel nos diz: "Faze aos outros o que gostarias que fizessem a ti". E na tradição islâmica, o Corão (52:36) afirma: “Ou criaram, acaso, os céus e a terra? Qual! Eles não crêem!”. Seriam esses os nossos valores?

Não há, evidentemente, uma tradição norte-americana única ou um conjunto único de valores norte-americanos. Há, e sempre houve, muitos Estados Unidos: cada um de nós tem em mente e evoca o da sua predileção. Os Estados Unidos da 
escravidão e do racismo são uma profunda tradição norte-americana, ainda muito presente. Os Estados Unidos do individualismo, dos desbravadores do Oeste e de facínoras e pistoleiros impetuosos são também uma tradição e muito presente. Há ainda os robber barons e seus herdeiros filantrópicos e, finalmente, os wobblies e as revoltas de Haymarket, manifestações celebradas em todo o mundo exceto nos Estados Unidos, onde são uma tradição norte-americana e presente ainda hoje.

Sojourner Truth, discursando perante o Congresso Nacional de Mulheres em 1851 e perguntando, "Não sou uma mulher?", é uma tradição norte-americana. Mas as sufragistas do final do século XIX, que reivindicavam o direito de votar argumentando que isso ajudaria a contrabalançar os votos dos negros e dos imigrantes, também são uma tradição norte-americana. Os Estados Unidos que recebem imigrantes de braços abertos e os Estados Unidos que os repudiam são, ambos, tradições norte-americanas. Os Estados Unidos que se unem em determinação patriótica e os que resistem a operações militares são também tradições. Não há uma essência aqui. Não há um "aqui” aqui. Como Gould bem lembra, é a variação, não a essência, que está no cerne da realidade. A questão é se a variação que existe entre nós vai diminuir, aumentar ou permanecer a mesma. No momento, ela me parece excepcionalmente elevada.

Osama bin Laden logo será esquecido, mas o tipo de violência política que chamamos de terrorismo certamente permanecerá conosco nos próximos 30 a 50 anos. O terrorismo é, sem dúvida, uma maneira bastante ineficaz de mudar o mundo. É contraproducente e gera forças repressoras, que tendem a eliminar o elenco imediato de seus protagonistas. Não obstante, o terrorismo continuará a existir. Um Estados Unidos que continue a se relacionar com o mundo afirmando unilateralmente que representa a civilização - seja sob a forma de um retraimento isolacionista ou de um intervencionismo ativo - não poderá viver em paz com o mundo e, portanto, não poderá viver em paz consigo mesmo. O que fazemos no mundo, fazemos também a nós mesmos. Será que a terra da liberdade e do privilégio, mesmo em seu declínio, conseguirá aprender a ser uma terra que trate todos em toda a parte como iguais? E será que nós, que não agimos com igualdade dentro de nossas fronteiras, conseguiremos atuar de igual para igual no sistema mundial?

O que decidiremos fazer agora? Posso ter minhas preferências, mas não posso, como ninguém pode, prever o que faremos. Na verdade, é uma bemaventurança não termos certeza acerca de nenhum desses futuros projetados. Isso nos reserva uma escolha moral, um possível mais rico que a realidade, nos reserva novidades imprevisíveis. Ingressamos numa era terrível, de conflitos e malignidade difíceis de imaginar - mas aos quais, infelizmente, podemos talvez rapidamente nos acostumar. É fácil embrutecer nossa sensibilidade na luta pela sobrevivência. Muito mais difícil é salvar nossas almas de caubói. Contudo, no final do processo existe uma possibilidade - que está longe de ser uma certeza - de um mundo materialmente mais racional, igualitário e democrático, de uma universali- 
dade que resulta de saber dar e receber, e que é o oposto da globalização.

A última metáfora associada às Torres Gêmeas é que aquelas estruturas eram, são e serão uma opção. Nós decidimos construí-las. Estamos decidindo se iremos ou não reconstruí-las. Os fatores que determinam tais escolhas eram, são e serão inumeráveis. Estamos reconstruindo os Estados Unidos. O mundo está reconstruindo o mundo. Os fatores que determinam tais escolhas eram, são e serão inumeráveis. Conseguiremos manter nossa postura moral diante da incerteza de saber que o mundo que criamos até hoje é apenas um dentre milhares de mundos alternativos que poderíamos ter criado; e que o mundo que estaremos criando nos próximos 30 a 50 anos pode ser melhor, ou não, pode reduzir, ou não, a contradição entre nossos ideais e nossos privilégios? In-sha 'a-llah-que seja feita a vontade de Deus.

Notas

1 Publicado em Theory and society, v. $21^{\circ}$, fev. 1992, p. 1-28.

2 Os autores são Jerry L. Martin e Anne Neal.

3 "Multiple kingdoms", London Review of Books, 19/7/01, p. 23.

4 Achebe, Chinua. Home and exile (Nova York: Anchor Books, 2000), p. 91.

5 Zizek, Slavoj. On belief (Nova York: Routledge, 2001), p. 152.

6 The New York Times, 28/11/01, p. E8.

7 Full house: the spread of excellence from Plato to Darwin (Nova York: Three Rivers Press, 1996), p. 41.

8 Prigogine, Ilya. The end of certainty: time, chaos and the new laws of nature (Nova York: Free Press, 1997), p. 72.

Immanuel Wallerstein é professor emérito de Sociologia da Universidade de Binghamton. Diretor do Fernand Braudel Center for the Study of Economics, Historical Systems and Civilizations. Presidente da International Sociological Association. Obras principais: Africa, the politics of independence (1961); Africa, the politics of unity (1967); The modern world-system, I (1974); II (1980); World-systems analysis: theory and methodology (com Terence K. Hopkins, 1982); Historical capitalism (1983); The modern world-system, III (1989); Transforming the revolution: social movements and the world-system (com Samir Amin, Giovanni Arrighi e Gunder Frank, 1990); Geopolitics and geoculture (1991); Unthinking social science (1991); After liberalism (1995); Utopistics: or historical choices of the 21st. century (1998); The end of the world as we know it (1999). Em português: Após o liberalismo: em busca da reconstrução do mundo (Vozes, 2002); Capitalismo histórico e civilização capitalista (Contraponto, 2001); Para abrir as Ciências Socias (Cortez, 1996). Tradução de Carlos Afonso Malferrari. Original disponível no IEA-USP para consulta. 